\title{
PEMANFAATAN TEKNOLOGI MEMBRAN REVERSE OSMOSIS (RO) PADA PROSES PENGOLAHAN AIR LAUT MENJADI AIR BERSIH
}

\author{
Aan Sefentry ${ }^{1)}$, Rully Masriatini ${ }^{2)}$ \\ ${ }^{1,2}$ ) Dosen Prodi Teknik Kimia Universitas PGRI Palembang \\ ${ }^{1)}$ email : aan73sefentry@gmail.com \\ ${ }^{2)}$ email: rullyfir@gmail.com
}

\begin{abstract}
ABSTRAK
Salah satu alternatif metode Pengolahan Air laut adalah dengan menggunakan membran.Pada penelitian ini digunakan membran Reverse Osmosis jenis selulosa. Sampel Penelitian diambil di daerah Sungsang Kabupaten Banyuasin Sumatera Selatan. Treatment awalnya digunakan pasir kuarsa dan karbon aktif. Penelitian ini bertujuan untuk mengolah air laut di daerah Sungsang menjadi air bersih. Hasil air bersih yang di hasilkan Turbidity 1,56 Ntu, Salinitas 0,40, TDS 27 dan pH 7. air produk RO di atas dapat disimpulkan bahwa air tersebut sudah memenuhi standar kadar maksimum yang sesuai dengan Peraturan Menteri Kesehatan No. 416/Permekes/IX/1990.
\end{abstract}

Kata Kunci : Membran, Reverse Osmosis, Pengolahan Air

\section{PENDAHULUAN}

Krisis kebutuhan air bersih sudah melanda sebagian wilayah di dunia. Letak geografis dan terus bertambahnya populasi manusia menjadi sebab permasalahan tersebut. Indonesia merupakan negara kepulauan yang dikelilingi oleh laut dan dikaruniai sumber daya alam yang melimpah, salah satunya adalah air. Air adalah sumber kehidupan karena mahluk hidup tidak akan dapat hidup tanpa air. Persentase air yang terdapat di bumi adalah sebesar $97 \%$ namun air yang layak dikonsumsi hanya berkisar $27 \%$ saja Dengan kata lain ketersediaan air yang terdapat di bumi sangatlah besar tetapi yang bisa digunakan jumlahnya sangat kecil. Langkanya ketersediaan air bersih ini menjadi masalah tersendiri di berbagai kota di Indonesia terutama kota-kota besar yang penduduknya padat dan aktivitasnya sangat banyak, polusi udara yang tinggi serta pengaruh hujan asam akan memberikan pengaruh yang buruk pada kualitas air yang dikonsumsi (Sri Redjeki, 2011). Nyatanya masih banyak daerah yang tidak dapat menikmati air bersih terutama air yang layak untuk dikonsumsi. Penyebabnya salah satunya adalah kurangnya sumber daya manusia yang dapat mengatasi permasalahan tersebut serta tidak mengenal jenis teknologi yang bisa mengatasi permasalahan tersebut.

Daerah Sungsang terletak di kabupaten Banyuasin provinsi Sumatera Selatan. Merupakan Desa Pesisir yang hampir sebagian penduduknya adalah nelayan. Terletak di wilayah paling ujung Sumatera dan mengarah ke Selat Sunda. Letak daerah Sungsang yang berada di daerah pesisir dan berdampingan dengan laut menyebabkan daerah ini kekurangan air bersih. Masyarakat daerah Sungsang mendapatkan air bersih dengan cara menampung air hujan di dalam drum drum plastik, selain itu mereka membeli air bersih yang harganya tergolong mahal mengingat penghasilan penduduk Sungsang hanyalah sebagai nelayan dengan penghasilan yang minim. Kondisi seperti ini tentu saja menyebabkan buruknya sanitasi di daerah tersebut dan dapat menyebabkan gangguan kesehatan 
(Cassandra, 2014). Air laut yang sangat berlimpah di di daerah ini dapat dimanfaatkan dan diolah menjadi air bersih dengan menggunakan teknologi membran yaitu Teknologi Reverse Osmosis (RO) agar kebutuhan air bersih masyarakat dapat terpenuhi.

Penggunaan membran Reverse Osmosis (RO) dan Nanofiltrasi (NF) untuk mengolah air laut dan air payau adalah pilihan yang tepat. Penggunaan membran ini menjadi menarik karena material yang dikembangkan untuk mendapatkan membran dengan fluks yang tinggi, tingginya rejeksi terhadap garam dan dapat digunakan pada tekanan rendah (R. Haddad, et.al, 2004)

Penelitian ini bertujuan untuk mengolah air laut menjadi air bersih layak konsumsi.. . Diharapkan hasil dari penelitian ini dapat memberikan banyak manfaat dan dapat diaplikasikan kepada masyarakat yang membutuhkan serta berguna untuk kepentingan akademis maupun non-akademis, dan formal maupun non-formal.

\section{TINJAUAN PUSTAKA}

Air merupakanmaterial yang sangat penting untuk semua mahluk hidup. Tanpa air tidak ada kehidupan di muka bumi ini. Berdasarkan kegunaannya air digolongkan seperti berikut ini : Air yang dapat langsung diminum tanpa diolah terlebih dahulu yaitu Golongan A, Air yang dapat digunakan sebagai air baku air minum (Golongan B), Air yang digunakan untuk keperluan perikanan dan peternakan (Golongan C) dan Air yang dapat digunakan untuk keperluan pertanian dan dapat dimanfaatkan untuk industri pembangkit listrik tenaga air (Golongan D) (Sri Redjeki, 2011). Kadar garam yang dimiliki air tawar adalah $0,05 \%$, apabila nilainya lebih dari nilai tersebut maka dikategorikan sebagai air payau, atau akan menjadi saline apabila konsentrasinya 3-5\% maka disebut juga saline water (Sofyana dkk, 2015).

Air laut merupakan air murni yang terdiri dari berbagai macam zat padat dan gas yang terlarut didalamnya. Garam-garam organik yang asalnya dari organisme hidup, adalah zat-zat yang terlarut di dalam air laut. Garam-garam anorganik yang berwujud ion-ion adalah fraksi yang terbesar dari bahan terlarut. Enam ion anorganik membentuk 99,28\% berat dari bahan anorganik padat. Ion-ion tersebut yaitu klor natrium belerang (sebagai sulfat), magnesium, kalsium, dan kalium. Lima ion berikutnya menambah $0.71 \%$ berat, hingga sebelas ion bersama-sama membentuk 99,99 \% berat zat terlarut. Diantara sisanya (0,01\%), terdapat beberapa garam anorganik yang berperan penting bagi biota-biota laut. Salah satunya adalah nutrien, yaitu fosfat dan nitrat, yang diperlukan oleh tumbuhan untuk mensintesa zat organik dalam fotosintesis, dan silikon dioksida yang dibutuhkan diatom dan radiolaria untuk membentuk cangkangnya (Sri Redjeki, 2011). 
Salah satu teknologi pengolahan air yang memiliki kinerja yang cukup tinggi yaitu dengan menggunakan teknologi membran. Beberapa keunggulan dari pemisahan dengan menggunakan membran adalah tidak memerlukan penambahan bahan kimia dan tidak membutuhkan energi yang besar (Husnah, 2018).

Teknologi membran sudah banyak diaplikasikan pada proses pemisahan, pemurnian dan pemekatan pada industri kimia dan pangan. Keunggulan utama dari teknologi ini adalah tidak ada fase yang berubah dari komponen yang dipisahkan selain itumenggunakan suhu proses yang rendah. Akibatnya energi yang dibutuhkan dari teknologi membran inicukup rendah, selain itu kerusakan bahan yang diakibatkan oleh suhu tinggi dapat dicegah.Pada dasarnya membran merupakanbarier semipermeable yang mampu melewatkan komponen tertentu namun menahan komponen yang lain hal ini dipengaruhioleh mekanisme pemisahan serta ukuran bahan yang dipisahkan. Berdasarkan cara pemakaiannya membran dibagi menjadi lima jenis, yaitu Mikrofiltrasi (MF), Ultrafiltrasi (UF), Nanofiltrasi (NF), Osmosa Balik atau Reverse Osmosis (RO), dan Elektrodialysis (ED) (Cheryan, 1998)

Salah satu teknologi membran yang banyak digunakan saat ini yaitu Reverse Osmosis(RO). Membran Reverse Osmosis didefinisikan sebagai membran semipermeabel yang mampu melakukan pemisahan air tawar dari larutan garam dengan tekanan yang lebih tinggi dari tekanan osmosa larutan garam. Pemisahan komponen terlarut berukuran 0,001 sampai $0,01 \mu \mathrm{m}$ dan partikel yang berat molekulnya rendah dapat dilakukan oleh membran Reverse Osmosis. Apabila membran semipermeabel memisahkan air tawar dan air garam, maka air tawar dan air garam akan mendifusi membran dan mengencerkan larutan garam. Peristiwa ini disebut Peristiwa Osmosa. Apabila tekanan air garam lebih tinggi dari tekanan osmosa, air yang terdapat dalam air garam didorong menuju air garam melalui membran semipermeabel maka peristiwa ini disebut Reverse Osmosa (Robiatun, 2003). Keunggulan dari teknologi Reverse osmosis ini dari teknologi yang lain antara lain adalah energi yang dibutuhkan relatif rendah, minimnya permasalahan korosi alat, kemudahan dalam penggantian dan pemasangan serta instalasinya yang mudah terintegrasi dengan sistem yang ada (C.B. Rasrendra \& Hanggara Sukandar, 2002).

Beberapa penelitian tentang Desalinasi air laut menggunakan teknologi Reverse Osmosis telah banyak dilakukan. Robiatun, 2003, meneliti pemurnian air laut menggunakan Membran Reverse Osmosis dimana penggunaan membran ini memberikan banyak keuntungan antara lain energi dan kapasitas yang dibutuhkan relatif kecil. Aplikasi Membran Reverse Osmosis untuk memenuhi kebutuhan air minum di daerah Pesisir diteliti oleh Nusa Idaman Said, 2003 dimana kadar garam air yang diolah dapat menurun hingga 98\% dan dapat langsung diminum karen telah bebas bakteri.

\section{METODELOGI PENELITIAN}

Pada penelitian ini membran yang digunakan adalah membran Reverse Osmosis jenis Selulosa. Tahapan penelitian yang dilakukan yaitu pembuatan membran reverse osmosis, melakukan uji sampel awal sebelum pengolahan, running alat dan pengujian sampel setelah diolah. Lokasi pengambilan sampel air laut untuk penelitian ini adalah di daerah Sungsang Kabupaten Banyuasin provinsi Sumatera Selatan. Berikut ini tahapan penelitian yang dilakukan tergambar dalam gambar 1.

Cara Kerja : 
1. Pengambilan sampel air baku kemudian dianalisa.

2. Air baku di bak penampungan dialirkan ke tabung pasir kuarsa melalui pompa kemudian dilakukan proses treatment awal untuk mengurangi kadar garam.

3. Selanjutnya air dialirkan ke housing membran ukuran $0,3 \mu$.

4. Alirkan air ke dalam unit karbon aktif.

5. Selanjutnya Air dialirkan ke membran keramik dan pengambilan sampel kedua.

6. Setelah itu masuk ke membran Reverse Osmosis (RO) guna menyaring sisa-sisa mineral dan partikel yang terkandung di dalam air dan pengambilan sampel ketiga.

7. Selanjutnya sampel dianalisa

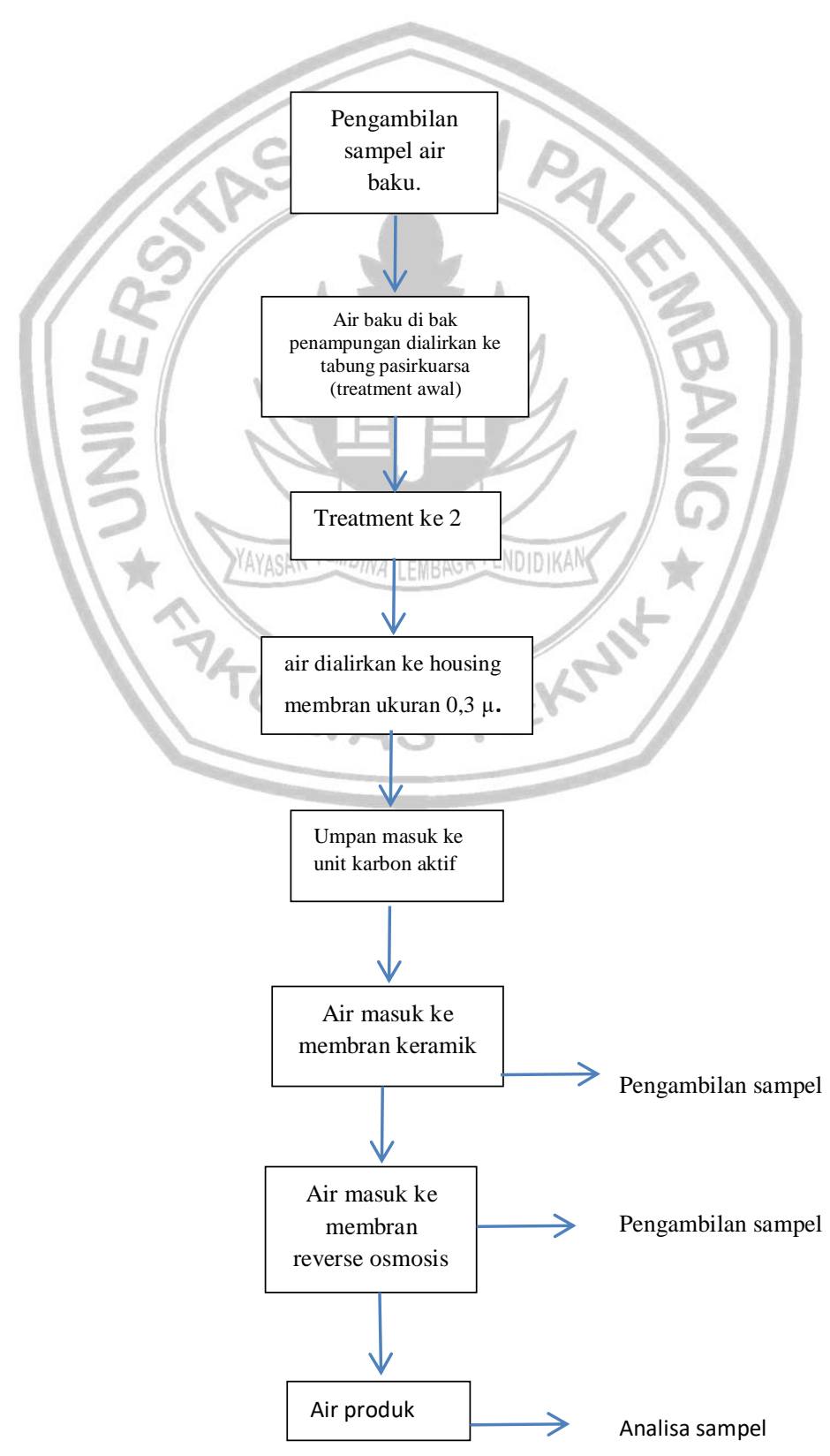

Gambar 1. Tahapan Penelitian 


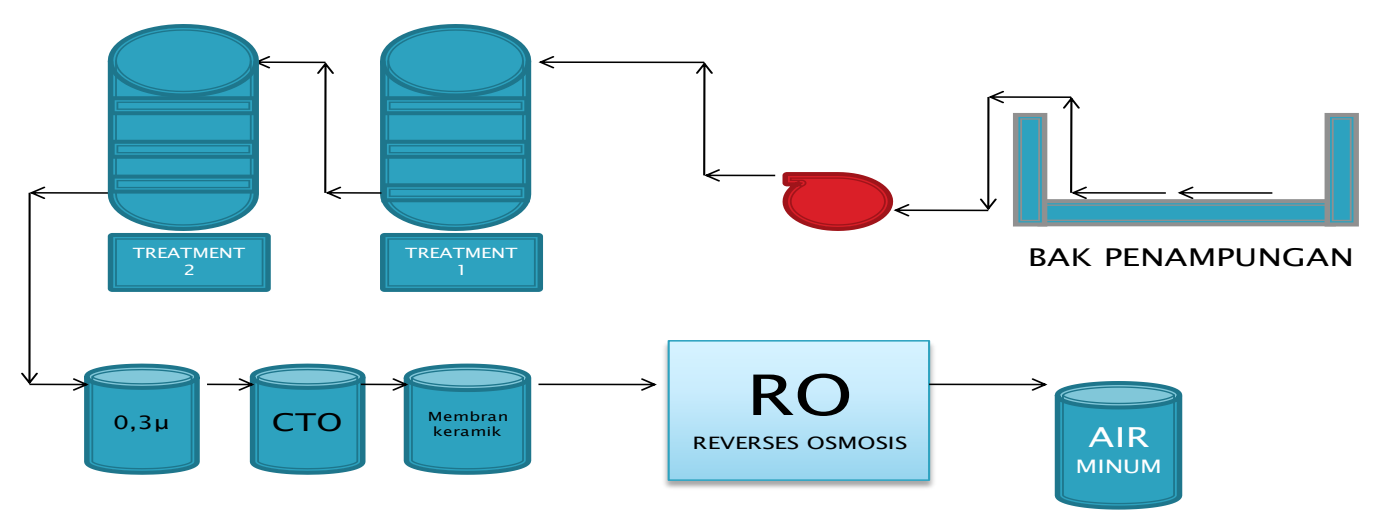

Gambar 2. Peralatan Pengolahan Air Laut menggunakan Membran Reverse Osmosis Hasil anaalisa sampel air baku adalah sebagai berikut

Tabel 1. Hasil analisa sampel air baku

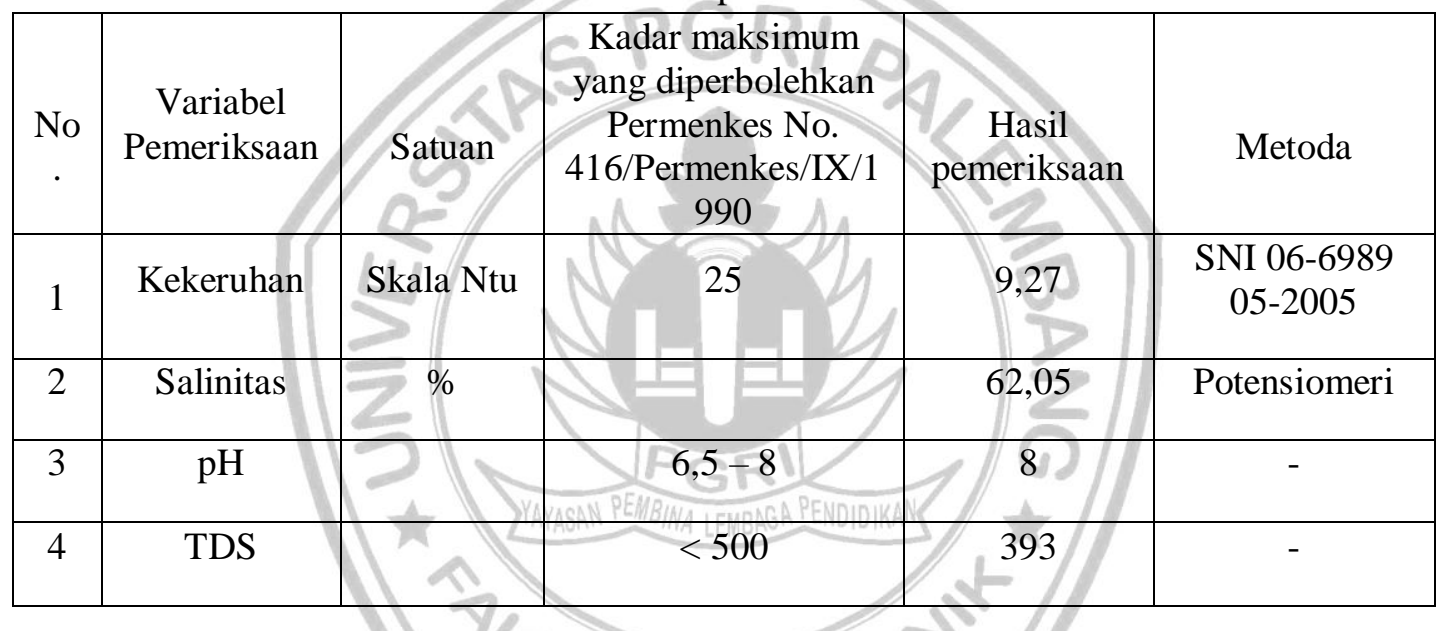

\section{HASIL DAN PEMBAHASAN}

Pada penelitian dengan metode eksperimen ini dilakukan sebanyak tiga kali percobaan. Didapat sebanyak tiga buah sampel, yaitu sampel air baku, sampel air proses dan sampel air produk. Selanjutnya dilakukan pengujian untuk ketiga sampel tersebut.

Hasil analisa sampel Air Proses dapat dilihat pada tabel 2

Tabel 2. Hasil analisa sampel Air Proses

\begin{tabular}{|c|c|c|c|c|c|}
\hline $\begin{array}{c}\text { No } \\
.\end{array}$ & $\begin{array}{c}\text { Item } \\
\text { pemeriksaan }\end{array}$ & Satuan & $\begin{array}{c}\text { Kadar maksimum yang } \\
\text { diperbolehkan } \\
\text { Permenkes }\end{array}$ & $\begin{array}{c}\text { Hasil } \\
\text { pemeriksaan }\end{array}$ & Metoda \\
\hline 1 & Kekeruhan & $\begin{array}{c}\text { Skala } \\
\text { Ntu }\end{array}$ & 25 & 1,72 & $\begin{array}{c}\text { SNI 06-6989 } \\
05-2005\end{array}$ \\
\hline 2 & Salinitas & $\%$ & $6,5-8$ & 2,90 & Potensiomeri \\
\hline 3 & pH & & $<500$ & 164 & - \\
\hline 4 & TDS & & $<, 5$ & - \\
\hline
\end{tabular}

Dari tabel hasil pengujian sampel air produk RO di atas dapat disimpulkan bahwa air tersebut sudah memenuhi syarat sebagai air bersih karena sudah sesuai dengan standar yang telah ditetapkan.

Tabel. 3 Hasil Pemeriksaan Air Produk RO 


\begin{tabular}{|c|c|c|c|c|c|}
\hline No. & $\begin{array}{c}\text { Item } \\
\text { pemeriksaan }\end{array}$ & Satuan & $\begin{array}{c}\text { Kadar maksimum yang } \\
\text { diperbolehkan } \\
\text { Permenkes }\end{array}$ & $\begin{array}{c}\text { Hasil } \\
\text { pemeriksaan }\end{array}$ & Metoda \\
\hline 1 & Kekeruhan & $\begin{array}{c}\text { Skala } \\
\text { Ntu }\end{array}$ & 25 & 1,56 & $\begin{array}{c}\text { SNI 06-6989 } \\
05-2005\end{array}$ \\
\hline 2 & Salinitas & $\%$ & $6,5-8$ & 0,40 & Potensiomeri \\
\hline 3 & pH & & $<500$ & 7 & - \\
\hline 4 & TDS & & & 27 & - \\
\hline
\end{tabular}

Dari tabel hasil pengujian sampel air produk RO di atas dapat disimpulkan bahwa air tersebut sudah memenuhi standar kadar maksimum yang sesuai dengan Peraturan Menteri Kesehatan No. 416/Permekes/IX/1990.

\section{KESIMPULAN}

Dari penelitian yang telah dilakukan dengan metode eksperimen serta dilakukan pengujian dan analisa dapat disimpulkan bahwa air laut yang diproses dengan teknologi membran Reverse Osmosis (RO) sudah cukup memenuhi standar kualitas air bersih sesuai Peraturan Memteri kesehatan No. 416/IX/1990 tentang Standar Kualitas Air Bersih dan Air Minum

\section{SARAN}

Perlu dilakukan penelitian lanjutan mengenai pengolahan air laut dengan membran ini dan dilakukan Analisa ataupun pengujian parameter-parameter lain seperti parameter/kimia maupun biologinya sehingga kualitas air yang dihasilkan lebih teruji.

\section{DAFTAR PUSTAKA}

Cassandra, 2014, Keadaan Desa Sungsang Sumatera Selatan, blogspot.com diakses dari http://kisahdarilautan.blogspot.com/2014/12/keadaan-desa-sungsang-sumatera selatan.html

C.B. Rasrendra \& Hanggara Sukandar, 2002, Desalinasi dengan Reverse Osmosis Tekanan Rendah, Departemen Teknik Kimia Institut Teknologi Bandung

Cheryan. M, 1998, Ultrafiltration and Microfiltration Handbook, Lancaster Techomic Publ. Inc

Husnah, 2018, Aplikasi Membran Keramik Buatan dengan Pretreatment pada Penjernihan Air Sungai Musi, Jurnal Redoks Program Studi Teknik Kimia Universitas PGRI Palembang, vol 3 no1, Periode Januari - Juni 2018

R. Haddad, E. Ferjani, S. Roudesli and A. Deratani, 2004, Properties of Cellulose Asetat Nanofiltration Membranes, Application to brackish water desalination, . J. Membr. Sci., 167, 403 -409 .

Robiatun, 2003, Membran Reverse Osmosis dalam Proses Desalinasi Airl Laut, Bulletin Penelitian Vol. XXV No.3, Desember 2003. 
Sofyana, Cut Meurah Rosnelly, 2015, Rekayasa Proses pembuatan Membran Nanofiltrasi dari Selulosa Asetat dalam Pemanfaatannya untuk pengolahan air baku yang memiliki Salinitas tinggi, Laporan Penelitian, Universitas Syiah Kuala

Sri Redjeki, 2011, Proses Desalinasi dengan Membran, Direktorat Penelitian dan Pengabdian kepada masyarakat (DP2M) Direktorat Jenderal Pendidikan Tinggi, Departemen Pendidikan Nasional .

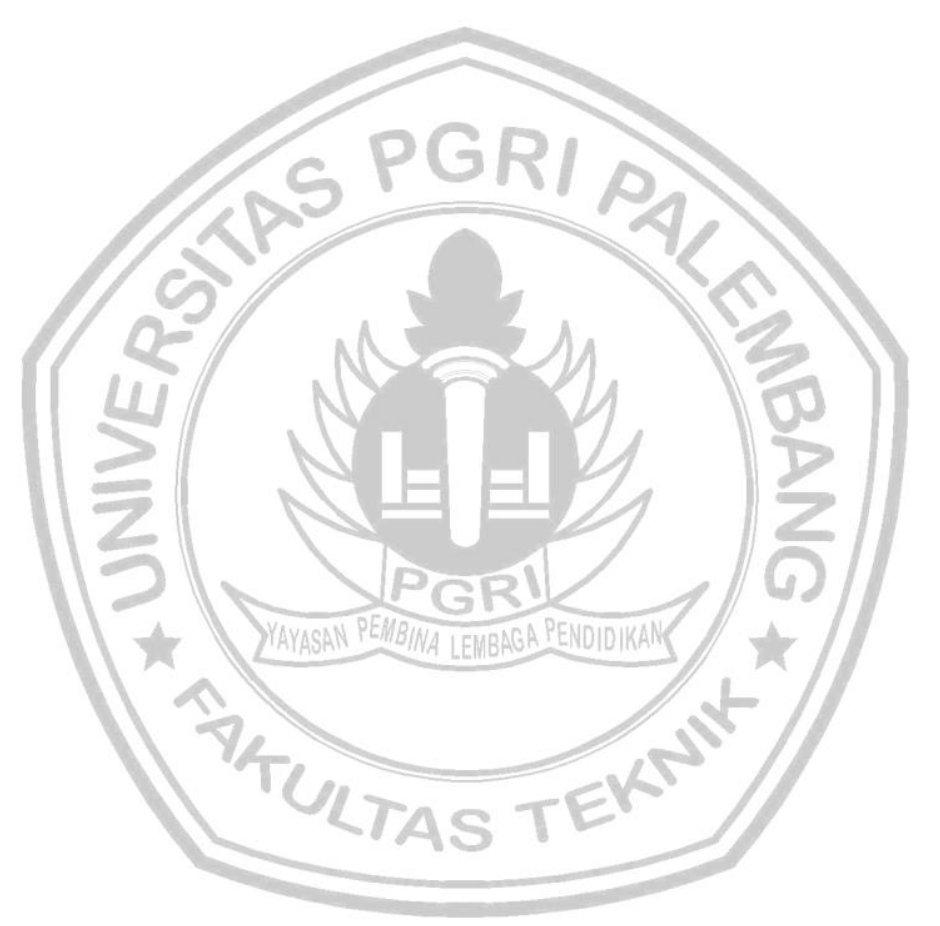

